\title{
The Impact of Social Inequities on Mortality Due to Pulmonary Tuberculosis in São Luis, Maranhão, Brazil

\begin{abstract}
Marcelino Santos Neto', Mellina Yamamura², Marcela Paschoal Popolin ${ }^{3}$, Ana Angélica Rêgo de Queiroz ${ }^{3}$, Luiz Henrique Arroyo4, Juliane de Almeida Crispim³, Flávia Menegheti Pieri ${ }^{5}$, Francisco Chiaravalloti Neto ${ }^{6}$, Maria Concebida da Cunha Garcia ${ }^{3}$, Ludmila Barbosa Bandeira Rodrigues7 ${ }^{7}$, Pedro Fredemir Palha ${ }^{8}$, Severina Alice da Costa Uchôa ${ }^{9}$, Aylana de Souza Belchior ${ }^{3}$, Ricardo Alexandre Arcêncio 8
\end{abstract}

\section{Abstract}

Introduction: Authors theorize about the relation between social inequities and death by tuberculosis. Nevertheless, the literature is restricted as to verifying the relation between these events in view of space. Therefore, the study objective was to identify areas with social inequity and its impact on the mortality rate by pulmonary tuberculosis.

Methods: Ecological study, which considered deaths from pulmonary tuberculosis in the urban area of the city between 2008 and 2012, available in Mortality Information System. For the construction of the social inequity indicator, the principal component analysis was used, Multiple linear regression with the least squares method and spatial regression were used to verify the impact of inequity on mortality by TB. The spatial dependence was confirmed using Moran's Global Index.

Results: 193 deaths were identified. The social inequity was statistically associated with the mortality $\left(R^{2}=23.86 \%\right)$ in the multiple linear regression model with spatial dependence (Moran $I=0.285 ; p<0.001$ ), which evidenced the highest rates of mortality in the weighted areas with high and intermediate social inequity.

Conclusion: Social inequity explains mortality by tuberculosis in the city investigated. To reduce the deaths by $95 \%$ until 2035 , the ac-
1 Professor PhD in Centre of Social Sciences, Health and Technology of the Federal University of Maranhão, Imperatriz, Maranhão, Brazil.

2 Postdoctorate in Interunit Doctoral Program of School of Nursing and Nursing College of Ribeirão Preto, University of São Paulo, São Paulo, Brazil.

3 Doctoral Student in Nursing College of Ribeirão Preto, University of São Paulo, São Paulo, Brazil.

4 Master Student in Nursing College of Ribeirão Preto, University of São Paulo, São Paulo, Brazil.

5 Professor PhD in Department of Nursing, University State of Londrina, Londrina, Paraná, Brazil.

6 Professor PhD in Department of Epidemiology, Faculty of Public Health, University of São Paulo, São Paulo, São Paulo, Brazil.

7 Professor PhD in Institute for Health Sciences, Federal University of Mato Grosso, Sinop, Mato Grosso, Brazil.

8 Professor PhD in Nursing College of Ribeirão Preto, University of São Paulo, São Paulo, Brazil.

9 Professor PhD in Department of Group Health, Federal University of Rio Grande do Norte, Natal, Rio Grande do Norte, Brazil

Contact information:

\section{Marcelino Santos Neto.}

Address: Centre of Social Sciences, Health and Technology of the Federal University of Maranhão (UFMA). Rua Urbano Santos, s/n Centro, Imperatriz, Maranhão, Brazil, CEP 65.900-000

Tel/Fax: (+55) (99) 98137-3510 ou (16) 3315-3429

\section{” marcelinosn@gmail.com}


tions the health authorities have established should not only promote better access to medical and diagnostic technologies, but also actions that promote the social development of the areas and their resident populations.

\section{Keywords}

Pulmonary Tuberculosis; Mortality; Spatial Analysis; Social Inequity.

\section{Introduction}

Tuberculosis (TB) is a great problem around the world, affecting 22 countries that concentrate $80 \%$ of the cases. About 1/3 of the population has been infected by the bacillus, making the disease hard to control. Brazil figures in that group, ranking $22^{\text {nd }}$ in terms of the incidence coefficient (33.5 cases per 100,000 inhabitants] and the mortality coefficient (2.3 deaths per 100,000 inhabitants) [1]. In that sense, in 2015, the End TB strategy was launched, which intends to reduce the mortality rate by $95 \%$ until 2035 and eliminate the disease by 2050 [2], imposing great challenges on the health services in Brazil.

Although the treatment is feasible and highly effective (95\% success rate], TB can be lethal in more than $50 \%$ of the cases that cannot be diagnosed or treated [3]. It is important to mention that, around the world, it is estimated that, in 2015, nine million people caught TB, but three million were not detected by the health services, part of them in Brazil [4].

The mortality in Brazil dropped by $20.7 \%$ in the last ten years, following the global trend. Nevertheless, in 2014, the mortality rate corresponded to 2.6 deaths for every 100,000 people [1]. The issue of TB mortality is an object that arouses concern because, from the ethical-human and legal viewpoints, it should not happen because of the available technological resources or inputs. Nevertheless, the organization and distribution logic of the health services does not permit access to all and precisely those who most need them have run out of these resources $[3,5]$.
Another aspect is that the mortality affects the economy, as the disease usually affects young people of economically active age $[6,7,8]$. Different studies have been developed to explain the determinants of TB mortality, such as age [9], sex [7], risk behaviors or habits, such as illegal drugs use [10], smoking [11], alcohol consumption [12] and association with HIV [13].

Some studies from different parts of World show that areas with vulnerable populations present higher mortality rate than those who live in areas with better social life conditions and health services $[14,15,16]$, for the last is easier to get diagnosis, treatment and obtain cure, for others patients this process is really more complex, difficult and likely tragic. These results evidence the intense inequality that exists in the world, however it is really stronger in TB High Burden Countries, including Brazil and a great challenge in Century $\mathrm{XXI}$ is overcoming in that. For achieve the "End TB", to reduce inequality is mandatory. No differently is Maranhão, which is a great State in Brazil with many problems related to social determinants as education, health, income distribution and housing, and all of these problems may have contributed for mortality due to TB.

The social inequities in mortality due to TB are omnipresent though [17]. The literature evidences that socially disadvantaged people, living in impoverished areas, without high-quality health services, tend to experience more health problems, more sequelae and a lower life expectancy [18, 19].

Although theoretical studies [17] suggest the relation between social inequities and mortality by TB, few studies have been undertaken to test this 
relation through explanatory models of causality [3]. In the study by Alvarez et al. [3], an interesting model of TB mortality was presented, incorporating the social inequities into the scope. Nevertheless, it was developed in European countries and did not incorporate the spatial dimension to explain the phenomenon.

The concept of social inequity in health rests on the definition by Whitehead and Dahlgren [18], which considers it as a vector resulting from the differences in health status among population groups of greater or lesser social and economic purchasing power. According to them, when the groups are compared, verifying that the groups at greater advantage are healthier, while less advantaged groups are less healthy, that characterizes the inequities; therefore, they are systematic, socially produced [modifiable] and unfair.

The evidence of the relation between social inequity and mortality by TB can contribute to the advancement of knowledge in this area and appoint the routes of the problem to governments and managers. Therefore, the study objective was to identify areas with social inequity and its impact on mortality by TB.

\section{Methods}

\section{Study design and scenery}

This is an ecological study [20] carried out in the city of São Luís, state of Maranhão, in the Northeast of Brazil (Figure 1) [21] Santos Neto et al [22] identified census sectors with the highest density of deaths per $\mathrm{Km}^{2}$; however, they did not establish the occurrence of these events in relation to the population's socioeconomic conditions.

\section{Population}

The study population consisted of all deaths from pulmonary tuberculosis (PTB) as primary cause registered in the Mortality Information System (SIM] from 2008 to 2012. The SIM is the Brazilian national

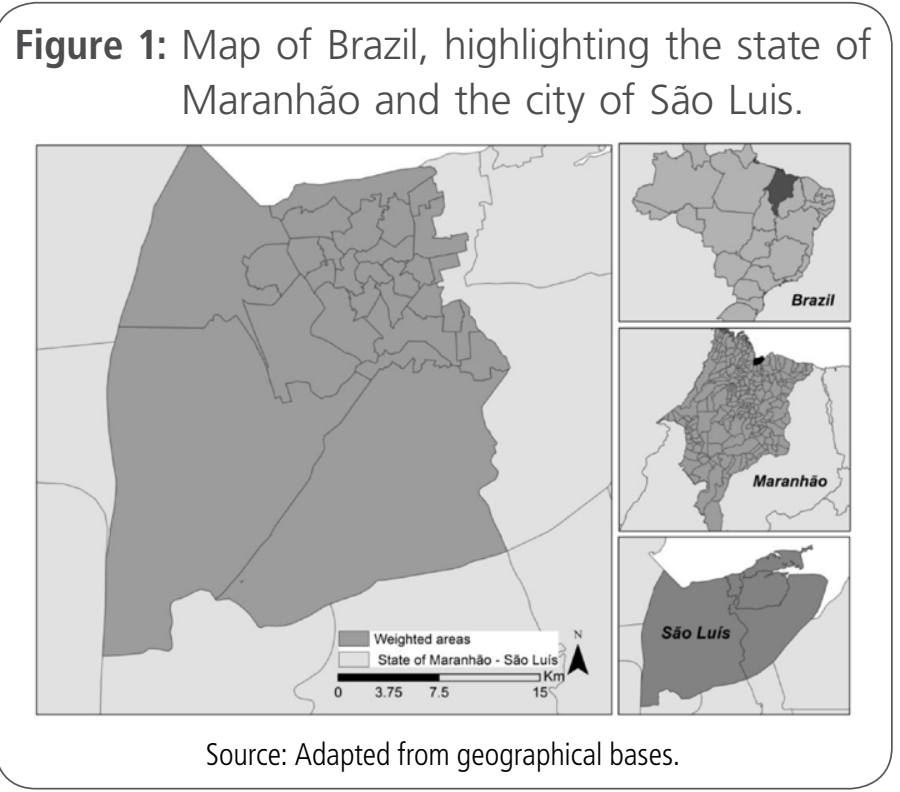

information system, which provides epidemiological and clinical information on the cases of deaths [23].

\section{Sources of data and Selection criteria}

The data were obtained of the Superintendence of Health and Epidemiological Surveillance of São Luis in July 2013. For the study, the deaths of people living in urban areas were considered, whose International Classification of Diseases version 10 ICD10 corresponded to the causes A15.0 to A15.3 and $A 16.0$ to $A 16.2$.

\section{Analysis of data}

Initially, case geocoding (deaths from PTB) was carried out, using TerraView 4.2.2. Spatial analysis was performed by area, using the weighted areas of the city as the spatial analysis unit, aiming to obtain death rates from PTB standardized by age (TMTBPi) for each weighted area according to the formula below:

$$
\text { TMTBPi }=\left(\frac{\sum \text { standardized by age deaths }}{\Sigma \text { standard population }} \times 100.000\right) / 5
$$

For the construction of the social inequity indicators, data from the analysis unit of the weighted areas related to dimensions of home conditions, income, education, clustering and water access were 
selected, outlined by the 2010 Demographic Census [24], a study the Brazilian Institute of Geography and Statistics develops every ten years, which joins information on the entire Brazilian population. The variables were selected according to the theoretical framework defined for the study [18]. In this research phase, Statistica 12.0 was used, when the component analysis technique was applied, which permitted selecting the most significant variables for each indicator [25].

The criteria proposed by Kaiser were used, in which only eigenvalues above one were considered [26]. Therefore, the correlation matrix of all the original variables and their components were examined, and the variance loads of these original variables were analyzed for each new component selected, considering values above 0.7 as acceptable [25].

Once the social indicators were selected and their characteristics were verified in terms of composition (variance) of original variables, their scores were calculated for the weighted areas, with subsequent thematic map design. Such scores were classified according to the quartiles (lower, interquartile and top).

After obtaining the file with the TBMPI and the classification of the weighted areas according to social indicators, the OpenGeoDa program version 1.0 was used for data transfer into the ASCII format, for reading in the program $R$ 3.0.2. In addition, a neighborhood matrix was formulated, using the criterion of distance from $k$ neighbors, considering the five nearest neighbors.

The files produced in the step mentioned earlier, together with the neighborhood matrix, were imported in the software $\mathrm{R}$, where the analysis of multiple linear regression by the least squares method was executed, followed by the spatial regression, which takes into account the existence of spatial dependence of the variables.

In the study the TMTBPi of the weighted areas was used as dependent variable and social indicators obtained as independent variables in the regression model, considering the model with the highest adjusted $R^{2}$ value as the preferred criterion to choose the best explanatory model.

Since the linear regression model was selected, the residues were investigated to evaluate the existence of spatial dependence by applying the Global Moran's I test, specific to regression residues [27]. After identifying the spatial dependence of the residue, the multiplier test of Lagrange was applied for the diagnosis of the best spatial regression model to be used, either the spatial lag or spatial error model.

The comparison between the obtained models was performed by comparing the values of the Akaike Information Criterion (AIC), which takes into account the maximum value of the log-likelihood and the number of model parameters. According to this criterion, the best model is the one with the smallest value of AIC [28]. The thematic maps were designed using the ArcGIS 10.1.

\section{Ethical considerations}

The study received approval from the Institutional Review Board at Escola de Enfermagem de Ribeirão Preto da Universidade de São Paulo (EERP/ USP) through the Certificate Presentation to Ethics Assessment (CAAE) No 12494113.0.0000.5393, according to the Guidelines and Regulatory Standards for Research Involving Human Beings.

\section{Results}

This study identified 193 deaths by PTB, of which 190 (98.44\%) had no mention of bacteriological or histological confirmation (ICD 16.2); 1 case (0.52\%) had no bacteriological or histological examination (ICD A16.1); 1 (0.52\%) had histologically confirmation (ICD A15.2] and, 1 (0.52\%) had confirmation by sputum microscopy with or without culture (ICD A15.0).

The percentage of geocoded deaths from PTB was 94.80\% (183 deaths). Of this total, 179 (98.00\%) were geocoded using the cartographic database of 
street addresses, and 4 (2\%) were geocoded using the tool Batch Geocode. The losses that occurred in the geocoding process $(n=10 ; 5 \%)$ were related to incomplete addresses in the SIM ( $n=4 ; 2 \%)$, street dwellers $(n=2 ; 1 \%)$ and addresses from the rural region of the city $(n=4 ; 2 \%)$. The distribution of TMTBPi according to weighted areas ranged from 0 to 8.10 deaths/100,000 inhabitants-year.

As regards the construction of the social indicators through principal components analysis, the first two components were selected, which carried $73.07 \%$ of the total variance. The first principal component
(CP1) corresponded to the highest variance explained by the data $(56.75 \%)$, followed by the second principal component (CP2) (16.32\%).

Table 1 presents the eigenvectors [also known as loadings] obtained through the eigenvalues. It can be observed that the number of loadings of CP1 superior to 0.7 was higher when compared to CP2. That is the case because the eigenvectors also accompany the degree of importance in terms of variance. In CP2, six variables presented loadings superior to 0.7 , relatively lower than CP1 with nine variables.

Table 1. Eigenvectors of the original variables for the construction of social indicators, São Luis, Maranhão (2008-2012).

\begin{tabular}{|c|c|c|c|}
\hline Variables & $\begin{array}{c}\text { Code of } \\
\text { variables }\end{array}$ & PC1 & PC2 \\
\hline Proportion of households with coated brick outer walls & V1 & 0.845 & 0.348 \\
\hline Proportion of households with uncoated brick outer walls & V2 & -0.639 & 0.624 \\
\hline Proportion of households with up to three rooms & V3 & 0.672 & 0.637 \\
\hline Proportion of households with three or more rooms & V4 & 0.918 & -0.037 \\
\hline Proportion of households with no monthly per capita income & V5 & 0.323 & -0.072 \\
\hline Proportion of households with monthly per capita income of up to $1 / 2$ minimum wage & V6 & -0.634 & 0.758 \\
\hline Proportion of households with monthly per capita income of more than $1 / 2$ a minimum wage & V7 & -0.745 & -0.618 \\
\hline $\begin{array}{l}\text { Proportion of households with monthly per capita income of more than one to two } \\
\text { minimum wages }\end{array}$ & V8 & 0.638 & -0.320 \\
\hline $\begin{array}{l}\text { Proportion of households with monthly per capita income of more than two to three } \\
\text { minimum wages }\end{array}$ & V9 & 0.843 & 0.210 \\
\hline $\begin{array}{l}\text { Proportion of households with monthly per capita income of more than three to five } \\
\text { minimum wages }\end{array}$ & V10 & 0.713 & -0.703 \\
\hline Proportion of households with monthly per capita income of over five minimum wages & V11 & -0.510 & -0.320 \\
\hline $\begin{array}{l}\text { Proportion of people with ten or more years of age with no education and incomplete } \\
\text { elementary education }\end{array}$ & V12 & -0.380 & 0.700 \\
\hline $\begin{array}{l}\text { Proportion of people with ten or more years of age with full elementary and incomplete high } \\
\text { school }\end{array}$ & V13 & -0.821 & -0.394 \\
\hline $\begin{array}{l}\text { Proportion of people with ten or more years old with full high school and incomplete higher } \\
\text { education }\end{array}$ & V14 & 0.714 & 0.075 \\
\hline Proportion of people aged 10 years or older with complete higher education & V15 & 0.822 & -0.020 \\
\hline Proportion of households with three residents & V16 & 0.602 & -0.701 \\
\hline Proportion of households with five residents & V17 & 0.493 & 0.393 \\
\hline Proportion of households with eight residents & V18 & -0.484 & 0.401 \\
\hline Proportion of households with 10 or more residents & V19 & -0.382 & 0.723 \\
\hline Proportion of households without access to piped water & V20 & -0.632 & 0.714 \\
\hline Proportion of households with access to piped water & V21 & 0.782 & -0.344 \\
\hline
\end{tabular}


Table 2. Linear regression model for mortality by pulmonary tuberculosis, São Luis, Maranhão (2008-2012).

\begin{tabular}{|c|c|c|c|c|}
$\begin{array}{l}\text { Intercept and } \\
\text { independent } \\
\text { variables }\end{array}$ & Estimate & $\begin{array}{c}\text { Standard } \\
\text { error }\end{array}$ & T value & P value \\
\hline $\begin{array}{l}\text { Intercept } \\
\text { Indicator of } \\
\text { welfare (PC1) }\end{array}$ & 3.583 & 0.410 & 8.736 & $0.237 e-08$ \\
\hline $\begin{array}{l}\text { Indicator of } \\
\text { social inequity }\end{array}$ & 0.705 & 0.123 & 0.397 & 0.695 \\
\hline (PC2) & & & 3.127 & 0.004 \\
\hline
\end{tabular}

*AIC: 129.63, (AIC for multiple linear regression: 132.19)

Table 3. Spatial regression model for mortality rates by pulmonary tuberculosis, São Luis, Maranhão (2008-2012).

\begin{tabular}{|c|c|c|c|c|}
$\begin{array}{l}\text { Intercept and } \\
\text { independent } \\
\text { variables }\end{array}$ & Estimate & $\begin{array}{c}\text { Standard } \\
\text { error }\end{array}$ & T value & P value \\
\hline $\begin{array}{l}\text { Intercept } \\
\text { Indicator of } \\
\text { social inequity } \\
\text { (PC2) }\end{array}$ & 3.390 & 0.715 & 4.741 & $2.230 \mathrm{e}-06$ \\
\hline Lambda & 0.494 & 0.219 & 3.132 & 0.002 \\
\hline
\end{tabular}

In the analysis of the social indicators, antagonistic characteristics of the components can be verified, in which CP1 exhibited better characteristics of the homes and education, higher income and better living conditions in terms of social wellbeing. The variables highlighted for CP1 permitted its description as an indicator of social wellbeing.

According to the criteria defined in the research, the areas scoring below the lowest quartile were classified with low levels of social wellbeing; in the interquartile with intermediary levels of social wellbeing and, in the highest quartile, high levels of social wellbeing. CP2, in turn, expressed unhealthy housing conditions, greater human agglomeration and low income, and was therefore described as a social inequity indicator, because it evidences less favorable social context variables, permitting the identification of weighted areas of low, interme- diary and high social inequity.

Table 2 presents the results of the multiple spatial linear regression model, considering the TMTBPi as the dependent variable and the indicators of social wellbeing and social inequity as independent variables. The application of Moran's Global Test I to the model residues, using the five closest neighbors as the neighborhood criterion, produced a significant coefficient (Moran I=0.285; $\mathrm{p}<0.001$ ) and demonstrated the existence of spatial dependence. The application of Lagrange's Multiplier Test, in turn, informed that the best model to treat the existing spatial dependence was the Spatial Error Model.

In Table 3, the results of the spatial error model are observed, in which the Lambda coefficient, the autoregressive spatial parameter, had a p-value of 0.032 . This model was considered better than the non-spatial model because its AIC coefficient was inferior to the coefficient obtained through the multiple linear regression model and because it produces residues without spatial dependence.

When visually comparing the classification map of the weighted areas according to the social inequity indicator with the TMTBPi (Figure 2), it can

Figure 2: Maps of social inequity indicator and mortality rates by pulmonary tuberculosis, São Luis, Maranhão (2008-2012)

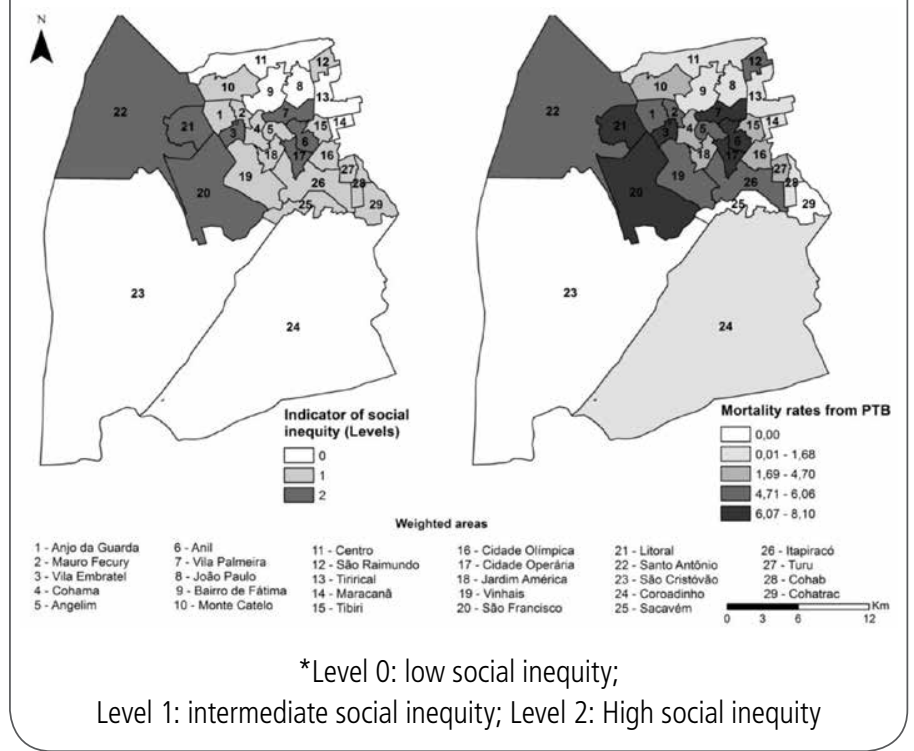


be evidenced the weighted areas with high social inequity presented higher mortality rates, ranging from 5.77 to 8.10 deaths/100,000 inhabitants-year. In addition, it is observed that weighted areas considered of intermediary social inequity presented mortality rates that ranged between 0.00 and 6.06 deaths/100,000 inhabitants-year.

In that sense, the statistically significant model, which explained the deaths, consisted of the social inequity indicator $(p=0.004)$, with an adjusted $R^{2}$ of $23.86 \%$ and a negative association with the rates mentioned.

\section{Discussion}

Critical areas in terms of social equity were verified, using a spatial regression model, in which its impact on TB mortality could be identified.

As for the diagnostic tests applied to confirm the cause of death by TB, an important percentage of certificates was found without bacteriological confirmation and/or culture, which was also confirmed by other studies in Campo Grande-MS [29] and in Rio de Janeiro [30]. This result refers to an important issue for the health systems and a critical obstacle they need to overcome, due to the possibility of false positives among deaths caused from PTB, since most had no mention of bacteriological or histological confirmation. The explanatory hypotheses for the finding include the lack of information records [31] and the non-prioritization of sputum smear microscopy in the hospital scenario [32].

Regarding the mortality from TB in Brazil, a downward trend in rates has been observed over the years, with a reduction of $2.9 \%$ per year. In 2011, the country achieved one of the targets of the Millennium Development Goals, which aimed for a $50 \%$ reduction in the mortality rate of 1990 [33]. Nevertheless, regional differences are remarkable in relation to deaths from this disease, especially in the Northeastern capitals of Brazil, which present rates above the national average [34].
By analyzing the map of the distribution of TMTBPi, which spatially appoints the areas with number of deaths/100,000 inhabitants-year, in São Luis, rates above the national average were observed for weighted areas considered with high inequity. The highest number of deaths from PTB among the less favored regions, from the social point of view, implies and justifies the intensification of actions related to the search for respiratory symptoms for early detection of cases, implementation of treatment and cure.

San Pedro and Oliveira [35], highlighted that TB remains a disease whose production process is closely related to the living conditions of the populations. Research conducted by Pereira, Cutrim Junior and Rodrigues [36], which aimed to analyze the indicators of conditions of intra-urban housing in São Luís and highlight their internal inequities, pointed out that the neighborhoods with the worst percentage are concentrated mainly in the peripheral areas of São Luís. Among these areas, the neighborhoods of Coroadinho, Ilhinha, Turu, Anjo da Guarda, Vila Nova, Vila Luizão, Vila Embratel, Sá Viana, Divinéia and the areas of Cidade Operária are highlighted. The authors also highlight the urban growth without previous planning, resulting in areas considered subnormal and which reveal inequities in the capital of Maranhão. These neighborhoods are located in the weighted areas that have been classified as areas of greater social inequity, considering the variables investigated in this study.

Curtis [19] points out that areas with high deprivation in relation to decent housing and sanitation, and therefore with greater social inequity, tend to experience health services with little problem solving ability and limitations in terms of supply and services offer. Although the health service network in the weighted areas of São Luis has not been investigated, there are reasons why the authors assume that there is a relationship among deaths, areas where the cases lived and health systems and services of these areas. 
Thus, higher or lower occurrence of deaths from PTB in different weighted areas is associated with population clustering and living conditions, since social indicators are highly relevant to the occurrence of this disease. It is noteworthy, therefore, that the spatial regression model constructed aimed to examine these possible associations. In the final model, it was observed that the indicator of social inequity was significantly associated with mortality from PTB, confirming the hypothesis that sustained the research.

With a view to the early identification of the existence of spatial dependence in the distribution of mortality rates from PTB standardized by age in São Luis during the spatial analysis procedures, the spatial autocorrelation of the residues of multiple linear regression were calculated in order to assess whether some correlation degree persists in these residues. The Moran's index was considered statistically significant, indicating spatial autocorrelation. The existence of one or more spatially conditioned factors not included in the model was sustained though, which also influences the mortality rate from pulmonary TB, since the adjusted $R^{2}$ value was of $23.86 \%$.

Therefore, the spatial analysis indicates that weighted areas in the city occupied without appropriate health infrastructure by a population of low income, low education and living in intradomiciliary clustering conditions had the highest mortality rates from PTB.

The research limitations include other variables that could explain the mortality rates from PTB in the scenario in question, since the presence of residual autocorrelation was observed in the multiple linear regression. The "ecological fallacy" should also be emphasized, since the observed results should be considered at an aggregated level and should not be interpreted at an individual level [37].

Despite the limitations, this research shows potentials, highlighting its originality, since other stud- ies evaluating the relationship between spatial distribution of deaths from PTB and social indicators in this scenario have not been observed. In addition, the study may help managers and health workers in the planning of health actions, surveillance and control of tuberculosis cases in the most critical areas. It also contributes to the public authorities in terms of rethinking public policies for social development and to meet the target set by $\mathrm{WHO}$, which aims for a 95\% reduction of deaths from TB by 2035 .

The study discussed the impact of social inequities on mortality by TB, as the indicator rises, that turns into an increase in the mortality rate, which is highly significant from the social, ethical and economic viewpoint. Thus, social protection measures are needed with a view to reaching the targets of reducing deaths by $95 \%$. The country is currently facing one of its worst [economic, political, ideological] crises, which has entailed cuts in education, health, housing, employment, among others. This will probably contribute to increased inequities and, in turn, a directive effect on TB mortality.

\section{Acknowledgments}

We are grateful to the Superintendence of Epidemiological and Health Surveillance of the Municipal Health Department in São Luís [MA] for the authorization to develop the research and for providing the data.

\section{Funding}

The authors would like to thank the Foundation for Scientific Research and Development of Maranhão (FAPEMA) and State of São Paulo Research Foundation (FAPESP), Process FAPESP \#2015/17586-3.

\section{Competing and Conflicting interest}

The authors declare that they have no competing interest. 


\section{Abbreviations}

TB: Tuberculosis; PTB: Pulmonary Tuberculosis; SIM: Mortality Information System; ICD-10: Classification of disease version 10; TMTBPi: Deaths Rate from Pulmonary Tuberculosis standardized by age; IBGE: Brazilian Institute of Geography and Statistics; AIC: Akaike Information Criterion; EERP: University of São Paulo at Ribeirão Preto College of Nursing; CP1: Principal Component 1; CP2: Principal Component 2.

\section{References}

1. World Health Organization (WHO). Global tuberculosis report 2015. Geneva: WHO; 2015.

2. World Health Organization (WHO). TB reach the 3 million: find, treat and cure. Geneva, 2014. 20 p. (cited 2015 Jan. 02) Available from: $\quad<$ http://www.stoptb.org/assets/documents/resources/ publications/acsm/WORLD TB DAY BROCHURE 14March.pdf>

3. Álvarez JL1, Kunst AE, Leinsalu M, Bopp M, Strand BH, Menvielle G et al. Educational inequalities in tuberculosis mortality in sixteen European populations. Int J Tuberc Lung Dis. 2011;15(11):1461-7.

4. Stop TB. Tb reach the 3 milion: find, treat and cure. Geneva, 2014. 20 p. (cited 2015 Mai 02) Available from: http://www. stoptb.org/assets/documents/resources/publications/acsm/ WORLD TB DAY BROCHURE 14March.pdf

5. Nikovska DG, Tozija F. Social determinants of equity in access to healthcare for tuberculosis patients in Republic of Macedonia - results from a case-control study. Int J Health Policy Manag. 2014; 3(4): 199-205

6 Mathers CD, Loncar D. Projections of Global Mortality and Burden of Disease from 2002 to 2030. PLoS Med. 2006; 3(11): e442.

7. Rathod SD, Timæus IM, Banda R, Thankian K, Chilengi R, Banda A. Premature adult mortality in urban Zambia: a repeated population-based cross-sectional study. BMJ Open 2016;6:3

8. Ram U, Jha P, Gerland P, Hum RJ, Rodriguez P, Suraweera W et al. Age-specific and sex-specific adult mortality risk in India in 2014: analysis of $0 \bullet 27$ million nationally surveyed deaths and demographic estimates from 597 districts. Lancet Glob Health. 2015;3(12):e767-75

9. Dale K, Tay E, Trevan P, Denholm JT. Mortality among tuberculosis cases in Victoria, 2002-2013: case fatality and factors associated with death. Int J Tuberc Lung Dis. 2016 Apr;20(4):515-23

10. Lucenko I, Riekstina V, Perevoscikovs J, Mozgis D, Khogali M, Gadoev J. Treatment outcomes among drug-susceptible tuberculosis patients in Latvia, 2006-2010. Public Health Action. 2014;4(Suppl 2):S54-8
11. Jeyashree K, Kathirvel S, Shewade HD, Kaur H, Goel S. Smoking cessation interventions for pulmonary tuberculosis treatment outcomes. Cochrane Database Syst Rev. 2016 ;(1):CD011125

12. Misganaw A, Mariam DH, Araya T. Association of socioeconomic and behavioral factors with adult mortality: analysis of data from verbal autopsy in Addis Ababa, Ethiopia. BMC Public Health 2013; 13:634.

13. Javalkar P, Prakash R, Isac S, Washington R, Halli SS. An Estimation of Mortality Risks among People Living with HIV in Karnataka State, India: Learnings from an Intensive HIVIAIDS Care and Support Programme. PloS One 2016; 11(6):e0156611. doi:10.1371/journal.pone.0156611.

14. Carneiro de Oliveira D, Salgado BA, Taracido TM, Figueiras GA al. Impact of socioeconomic inequities on the mortality of the City of Fortaleza, Ceara, Brazil during 2007. Revista Española de Salud Pública. 2010; 84:443-52.

15. Choi MH, Cheong KS, Cho BM, Hwang IK, Kim CH, Kim MH, Kwang SS, Lim JH, Yoon TH. Deprivation and mortality at the town level in Busan, Korea: an ecological study. Journal of Preventive Medicine and Public Health. 2011; 44: 242-48.

16. McCartney D, Scarborough $P$, Webster P, Rayner M. Trends in social inequalities for premature coronary heart disease mortality in Great Britain, 1994-2008: a time trend ecological study. BMJ Open. 2012; 2:1- 8.

17. Hargreaves JR, Boccia D, Evans CA et al. The social determinants of tuberculosis: from evidence to action. Am J Public Health 2011; 101: 654-62.

18. Whitehead Göran Dahlgren. Concepts and principles for tackling social inequities in health: Levelling up Part 1. World Health Organization 2006, reprinted 2007.

19. Curtis S. Health and Inequality: Geographical Perspectives. London: Sage Publications; 2009.

20. Fronteira I. Estudos Observacionais na Era da Medicina Baseada na Evidência: Breve Revisão Sobre a Sua Relevância, Taxonomia e Desenhos. Acta Med. Port. 2013; 26(2):161-70.

21. Instituto Brasileiro de Geografia e Estatística (IBGE) (internet). Mapas: bases e referenciais. Rio de Janeiro: IBGE, 2014 (cited 2014 Jan 15). Available from: http://mapas.ibge.gov.br/bases-ereferenciais/bases-cartograficas/cartas/.

22. Santos Neto M, Yamamura M, Garcia MCC, Popolin MP, Silveira TRS, Arcêncio RA. Análise espacial dos óbitos por tuberculose pulmonar em São Luís (MA). J Bras Pneumol 2014; 40:543-51.

23. Rocha MS, Oliveira GP, Aguiar FP, Saraceni V, Pinheiro RP. Do que morrem os pacientes com tuberculose: causas múltiplas de morte de uma coorte de casos notificados e uma proposta de investigação de causas presumíveis. Cad. Saúde Pública. 2015; 31(4): 709-21.

24. Instituto Brasileiro de Geografia e Estatística (IBGE). Censo demográfico 2010: resultados gerais da amostra. Rio de Janeiro: IBGE, 2012. p. 51. (cited 2015 Jan 21) Available from: ftp://ftp. ibge.gov.br/Censos/Censo Demografico 2010/Resultados Gerais_da_Amostra/resultados_gerais_amostra.pdf 
25. Spencer NH. Essentials of Multivariate data Analysis. CRC PRESS: Taylor \& Francis Group, 2014.186 p.

26. Ferraudo AS. Técnicas de análise multivariada - uma introdução. Apostila de Treinamento. Universidade Estadual Paulista (UNESP) 2012: 76 p.

27. Andrade FR. Ocorrência da dengue em Santana de Parnaíba e relação com medidas de controle. (Especialização em Saúde Pública). Faculdade de Saúde Pública da Universidade de São Paulo; 2012.

28. Burnham KP, Anderson DR Model selection and multimodel inference: A practical information-theoretic approach. 2010: $110 p$.

29. Espindola LCD. Estudo da mortalidade por tuberculose em Campo Grande - MS, 2001 a 2008. (Dissertation). Escola Nacional de Saúde Pública; 2010.

30. Selig L, Belo M, Cunha AJLA. Óbitos atribuídos à tuberculose no Estado do Rio de Janeiro. J Bras Pneumol. 2004; 30:417-24.

31. Oliveira GP, Pinheiro RS, Coeli CM, Barreira D, Codenotti SB. Uso do sistema de informação sobre mortalidade para identificar subnotificação de $=$ casos de tuberculose no Brasil. Rev Bras Epidemiol. 2012; 15:468-77.

32. Cecílio HPM, Fernandes CAM, Mathias TAF, Marcon SS. Perfil das internações e óbitos hospitalares por tuberculose. Acta paul. Enferm. 2013; 26:250-55.

33. World Health Organization (WHO). The global plan to stop TB 2011-2015: transforming the fight towards elimination of tuberculosis - reprinted with changes. Geneva, 2011. 92 p. (cited 2015 Jan 10) Available from: <http://whqlibdoc.who.int/ publications/ 2010/9789241500340 eng.pdf>

34. Brasil. Ministério da Saúde. Secretaria de Vigilância em Saúde. Programa Nacional de Controle da Tuberculose. Manual de recomendações para o controle da tuberculose no Brasil. Série B. Textos Básicos de Saúde. Brasília, DF: Ministério da Saúde, 2011.

35. San Pedro A, Oliveira RM. Tuberculose e indicadores socioeconômicos: revisão sistemática da literatura. Rev Panam Salud Pública. 2013; 33:294-301.

36. Pereira PRM, Cutrim Júnior V, Rodrigues ZMR. Desigualdades intraurbanas dos indicadores de saneamento em São Luís - MA. In: VI Jornada Internacional de Políticas Públicas, 2013 Resumos. São Luís: UFMA; 2013: 1-10.

37. Medronho RA, Carvalho DM, Block KV, Roner LB, Werneck V, Guilherme L. Epidemiologia. São Paulo: Editora Atheneu; 2006.

Publish in International Archives of Medicine

International Archives of Medicine is an open access journal publishing articles encompassing all aspects of medical science and clinical practice. IAM is considered a megajournal with independent sections on all areas of medicine. IAM is a really international journal with authors and board members from all around the world. The journal is widely indexed and classified Q1 in category Medicine. 